\title{
DILEMA PERKAWINAN ADAT SUMBAWA DI MASA PANDEMI COVID-19
}

\author{
Fatihatul Anhar \\ Azzulfa \\ UIN Sunan Kalijaga \\ Yogyakarta \\ fafika30@gmail.com
}

\section{Afnan Riani Cahya Ananda}

UIN Sunan Kalijaga

Yogyakarta

afnanananda4@gmail.com

\begin{abstract}
The procession of traditional marriage is a custom in the community that contains all rituals and require the implementation that must done by many people. The dilemma that occurs in the people of Sumbawa is a problem that must be faced together between the community and the government. This paper tries to explore and examine how the practice of traditional Sumbawa marriage when the Covid-19 pandemic took place in Brang Biji Village, Sumbawa District, Sumbawa Besar Regency. This research is a field research using descriptive analytical method. In this case, the local government has issued a policy during a pandemic Covid-19 to any person who performs his business to always implement health protocols. Meanwhile, the community understands that the traditional marriage procession must always be carried out and the pandemic is not a barrier. The obligation to carry out a traditional marriage procession is not regulated in terms of harmony or marriage conditions, but this customary procession does not contradict Islamic law. Marriage will remain valid if it is carried out in harmony and legal conditions of marriage according to Islamic law without carrying out the traditional procession in marriage. The government should provide an understanding to the community that during the Covid-19 pandemic, traditional marriage processions brought more mafsadah than benefits. Traditional procession becomes less meaningful if it ultimately brings bad consequences to himself or others
\end{abstract}

Keywords: the traditional marriage of Sumbawa and the covid-19 pandemic.

Abstrak: Prosesi perkawinan adat merupakan
suatu kebiasaan dalam masyarakat yang berisi
segala ritual dan mengharuskan pelaksanaannya
dilakukan oleh banyak orang. Dilema yang

The Indonesian Journal of Islamic Family Law

Volume 10, Nomor 02, Desember 2020; ISSN:2089-7480 
terjadi di masyarakat Sumbawa menjadi sebuah masalah yang harus dihadapi bersama-sama antara masyarakat dan pemerintah. Tulisan ini mencoba mengeksplorasi serta menelaah bagaimana praktik perkawinan adat Sumbawa saat pandemi Covid-19 berlangsung di Kelurahan Brang Biji Kecamatan Sumbawa Kabupaten Sumbawa Besar. Penelitian ini merupakan penelitian lapangan (field research) yang menggunakan metode deskriptif analitis. Dalam hal ini, pemerintah daerah telah mengeluarkan kebijakan selama pandemi Covid19 bagi setiap orang yang melaksanakan urusannya untuk selalu menerapkan protokol kesehatan. Sementara itu, masyarakat memahami bahwa prosesi perkawinan adat harus selalu dilaksanakan dan pandemi tidak menjadi penghalang. Kewajiban dalam melaksanakan prosesi adat perkawinan tidak diatur dalam rukun maupun syarat nikah, namun prosesi adat ini pun tidak bertentangan dengan Hukum Islam. Perkawinan akan tetap sah jika dilaksanakan dengan rukun dan syarat sah nikah sesuai Hukum Islam tanpa melaksanakan prosesi adat dalam perkawinan. Pemerintah seharusnya memberikan pemahaman pada masyarakat bahwa selama pandemi Covid-19 prosesi perkawinan adat lebih banyak mendatangkan mafsadah daripada kemanfaatan. Prosesi adat pun menjadi kurang bermakna jika pada akhirnya mendatangkan akibat buruk pada diri sendiri atau orang lain.

\section{Pendahuluan}

Kata Kunci: perkawinan adat Sumbawa dan pandemi covid-19.

Indonesia memiliki budaya yang beragam. Keragaman budaya di Indonesia adalah suatu hal yang tidak dapat dihindari. Keragaman sebuah budaya mewujudkan manifestasi dan nilai sehingga saling menguat, meningkatkan, serta mengapresiasi.1 Keragaman budaya ini tidak membuat Indonesia menjadi pecah.

1 Sugeng Pujileksono, Pengantar Antropologi, (Malang: Kelompok Intrans Pubising, 2015), 52. 
Kebudayaan adalah suatu kebiasaan dan tindakan yang dilakukan dalam waktu yang lama serta disepakati oleh masyarakat setempat.

Hubungan antara kebudayaan dan manusia erat kaitannya dengan kehidupan sehari-hari manusia yang tidak terlepas dari kebudayaan, seperti dalam hal makan hingga cara berpakaian.2 Kebudayaan yang berkembang di masyarakat merupakan perwujudan pemikiran manusia berupa tanda dan simbolsimbol serta memiliki makna. Terhadap budaya-budaya yang sudah ada sejak dulu, banyak masyarakat yang tidak secara langsung mengetahui makna dan nilai di balik simbol-simbol sehingga hanya menjalani tanpa mengetahui nilai filosofisnya. 3

Kebudayaan adalah warisan leluhur yang memiliki peranan penting di kehidupan masyarakat, khususnya adat yang hadir pada proses perkawinan adat. Adat perkawinan merupakan bagian dari prosedur yang harus dilaksanakan guna menyatukan dua insan dalam membina rumah tangga. Setiap daerah memiliki tradisi dalam melaksanakan perkawinan. Dalam hal ini, masyarakat Sumbawa masih mengikuti tradisi yang dipakai sudah ada sejak zaman para leluhurnya dalam hal perkawinan.

Perkawinan merupakan fitrah manusia antara laki-laki dan perempuan yang saling mengikat janji suci sehidup semati dengan berdasarkan Ketuhanan Yang Maha Esa. Dalam pemenuhan kebutuhan perkawinan di Indonesia, bukan hanya memenuhi syarat agama dan kepercayaan saja tetapi juga harus bisa memenuhi persyaratan administrasi perkawinan seperti yang tercantum dalam pasal 2 Undang-Undang No. 1 tahun 1974 Tentang Perkawinan. Pada pasal 2 undang-undang ini dinyatakan bahwa mengikatnya pria dan wanita dalam ikatan perkawinan yang bertujuan untuk membentuk keluarga yang kekal dan bahagia berdasarkan Ketuhanan Yang Maha Esa, menunjukkan adanya hubungan yang erat antara perkawinan

2 Ibid., 53.

3 Novi Widya Utami, "Wujud Kebudayaan dalam Prosesi Barodak Ritual Adat Pernikahan Sumbawa”, dalam Jurnal Retorika, Vol. 9, No. 2 (Agustus 2016), 121. 
dengan agama atau kerohanian.4 Sehingga dalam perkawinan bukan hanya untuk memenuhi kebutuhan secara lahir saja tetapi untuk memenuhi unsur batin atau rohani.

Pada dasarnya, yang terpenting dalam perkawinan ialah persetujuan dan kerelaan, yaitu antara mempelai laki-laki dan mempelai perempuan. Kerelaan adalah hal yang tidak dapat dilihat ataupun diukur. Oleh karena itu, bentuk persetujuan dan kerelaan itu dituangkan dalam ijab qabul. Ijab adalah penyerahan dari pihak pertama, sedangkan qabul adalah penerimaan dari pihak kedua.5 Ijab qabul merupakan salah satu rukun yang harus terpenuhi dalam melakukan perkawinan. Tanpa ijab qabul tidaklah sah perkawinan antara keduanya.

Adat istiadat yang dianut oleh masyarakat Sumbawa dalam bentuk orisinil mempunyai struktur hukum adat tersendiri. Sistem hukum yang mendarah daging di masyarakat memiliki perbedaan antar kelompok masyarakat yang satu dengan yang lainnya dan tersebar di berbagai daerah. Prosesi perkawinan masyarakat Sumbawa tidak memiliki perbedaan secara signifikan dengan masyarakat di berbagai wilayah di Indonesia, namun adat istiadat yang menyertai prosesi itu memiliki keunikan tersendiri.

Konsep prosesi perkawinan adat banyak dikenal oleh masyarakat, hanya saja beberapa tradisi lama sudah mulai berubah menjadi modern. Upacara perkawinan khususnya di daerah Sumbawa, tidak pernah terlepas dari prosesi perkawinan adat yang memiliki simbol-simbol yang berisikan pesan. Dalam upaya melestarikan dan mewariskan tradisi pada generasi muda, perlu diberikan pengetahuan yang mendalam mengenai adat istiadat dan nilai-nilai yang terkandung didalamnya.

Masyarakat suku Sumbawa merupakan salah satu dari banyak suku yang masih menjalankan upacara atau prosesi perkawinan adat. Sifat kebersamaan masyarakat dalam

4 Undang-Undang No. 1 Tahun 1974 tentang Perkawinan, Pasal 2.

5 Amir Syarifuddin, Hukum Perkawinan Islam di Indonesia Antara Fiqh Munakahat dan Undang-Undang Perkawinan, (Jakarta: Kencana, 2007), 61. 
keberagaman dalam segala kegiatan menjadikan masyarakat yang rukun dan mejadi salah satu fungsi sosial dari upacara perkawinan. Prosesi adat juga memiliki keunggulan yakni sebagai bahan renungan bagi masyarakat di era yang modern ini.

Keterlibatan masyarakat dalam melakukan segala kegiatan dan melakukan pembagian kerja serta memberikan bantuan seperti uang ataupun jasa juga dilihat sebagai fungsi sosial. Hal ini menjadikan kokoh dan semakin kuat solidaritas di antara anggota masyarakat. Prosesi perkawinan adat ini merupakan hal yang perlu dipertahankan karena mengandung nilai-nilai sosial dan menyebabkan masyarakat berinteraksi dengan efektif. Prosesi ini juga menghasilkan tingkah laku positif dari masyarakat.

Dalam prosesi perkawinan adat Sumbawa, ada beberapa tingkatan adat yang harus dilaksanakan sebelum dilakukannya upacara perkawinan, di antaranya adalah bajajak, bakatoan, saputis leng, nyorong, barodak, nikah dan basai'. Tujuh tahapan ini merupakan rangkaian proses yang di dalamnya terdapat benda-benda atau alat-alat adat dan simbol-simbol yang mempunyai makna tersendiri. Nilai dan norma yang terdapat dalam prosesi ini memiliki arti yang sakral pula dalam masyarakat.6

Ketika wabah Covid-19 ini muncul di Indonesia yang sebelumnya merebak di China, wabah tersebut berdampak buruk terhadap segala hal baik perekonomian, pariwisata hingga kesehatan juga merubah segala tatanan kehidupan masyarakat dunia, berbagai negara yang terpapar Covid-19 termasuk negara Indonesia dengan cepat membuat rencanarencana strategis terkait kebijakan tanggap darurat dengan memobilisasi seluruh sumber daya untuk memerangi wabah ini.7

6 Bapak Darmo (Masyarakat), Wawancara, Kelurahan Brangbiji, Kecamatan Sumbawa, 25 November 2020.

7 Muhyiddin, "Covid-19, New Normal dan Perencanaan Pembangunan di Indonesia", The Indonesian Journal of Development Planning, Vol. IV, No. 2 (Juni, 2020), 241. 
Pemerintah melalui Kementerian Agama mengeluarkan Surat Edaran Menteri Agama Nomor 15 Tahun 2020 tentang Panduam Penyelenggaraam Kegiatan Keagamaan di Rumah Ibadah dalam Mewujudkan Masyarakat Produktif dan Aman Covid di Masa Pandemi. Secara global kebijakan tersebut berisi pembatasan skala besar atas segala kegiatan termasuk prosesi perkawinan yang tidak diperkenankan diadakan secara ramai seperti sedia kala. Tetapi realitanya berbanding terbalik seperti praktik perkawinan adat pada masyarakat adat Sumbawa.8

Kajian mengenai praktik perkawinan pada masyarakat adat Sumbawa memiliki keunikan tersendiri untuk dijadikan penelitian dalam berbagai macam perspektif, seperti tulisan Qalbi Triudayani L. Patau yang berpendapat, bahwa tradisi perkawinan adat Sumbawa salah satunya Tradisi Barodak Rapancar wajib dilaksanakan saat perkawinan berlangsung karena merupakan rangkaian adat yang harus dilestarikan dan adanya ketakutan sanksi adat jika tidak dilaksanakan.9 Novi Widya Utami memaparkan bahwa pelaksanaan perkawinan dengan melibatkan adat Sumbawa dalam budaya barodak merupakan sebuah wujud kebudayaan sebagai suatu ide, gagasan, norma peraturan dan sebagai suatu kompleks aktivitas serta tindakan berpola dari manusia dalam masyarakat serta sebagai hasil karya manusia.10 Pelaksanaan tradisi tersebut sebagai media dalam menyampaikan pesan adat di wilayah Sumbawa. Selanjutnya Siti Arafah menjelaskan bahwa hadirnya Covid-19 berdampak besar pada perilaku masyarakat terutama dalam melaksanakan tradisi atau ritual perkawinan.11 Sebagian

8 Yapiter Marpi, "Keabsahan Hukum Pernikahan Tanpa Adanya Walimatul Ursy di Masa Kahar Pandemi Covid-19", As-Syar'i: Jurnal Bimbingan \& Konseling Keluarga, Vol. 2, No. 2 (2020), 184.

9 Qalbi Triundayani L. Patau, "'Urf Terhadap Tradisi Barodak Rapancar Sebelum Perkawinan”, Sakina: Journal of Family Studies, Vol. 5, No. 1 (2021), 1-12.

10 Novi Widya Utami, "Wujud Kebudayaan dalam Prosesi Barodak Ritual Adat Pernikahan Sumbawa", Jurnal Retorika, Vol. 9, No. 2 (Agustus, 2016), 120130.

11 Siti Arafah, "Pernikahan "Bersahaja" di Masa Pandemi Covid-19 Pada Masyarakat Bugis Kota Palopo”, Mimikri, Vol. 6, No. 2 (November, 2020), 171187. 
masyarakat memilih untuk tidak melakukan keseluruhan tradisi perkawinan, namun terdapat pula masyarakat yang enggan meninggalkan ritual atau tradisi perkawinan dengan alasan jika tidak dilaksanakan maka akan mendapatkan sanksi adat. Berikutnya tulisan dari Yuyun Yulianah dkk. yang mengemukakan bahwa perkawinan merupakan sebuah penyempurna agama tetapi melihat kondisi saat ini yang belum stabil akibat Covid-19 seharusnya seluruh masyarakat bersinergi bersama dengan tidak melakukan perhelatan secara besar-besaran dalam acara perkawinan demi menjaga keselamatan bersama.12

Pemberlakuan protokol kesehatan di masa pandemi Covid-19 sejauh ini tidak mempengaruhi pelaksanaan ritual adat khususnya di Sumbawa. Di masa Pandemi ini adat perkawinan dilakukan mengikuti protokol kesehatan dengan membatasi jumlah orang yang hadir, mamakai masker dan mencuci tangan. Hal ini sama sekali tidak mengurangi khidmat pelaksanaan adat perkawinan. Akan tetapi, dalam menerapkan protokol kesehatan ternyata masih ada dilema di masyarakat mengenai pelaksanaan adat dalam pernikahan walaupun prosesnya telah disederahanakan.

Berbeda dengan riset di atas, tulisan ini mencoba mengeksplorasi serta menelaah bagaimana praktik perkawinan adat Sumbawa saat pandemi Covid-19 berlangsung di Kelurahan Brang Biji Kecamatan Sumbawa Kabupaten Sumbawa Besar. Penelitian ini merupakan penelitian lapangan (field research) yang menggunakan metode deskriptif analitis, yaitu metode penelitian yang bertujuan memberi suatu gambaran secara sistematis, faktual dan akurat berdasarkan fakta-fakta yang ditemukan untuk kemudian dianalisis. Riset lapangan dilaksanakan pada bulan November 2020 dengan data primer didapatkan dari hasil wawancara dengan Pegawai Pencatat Nikah (PPN) KUA Kecamatan Sumbawa serta masyarakat yang

12 Yuyun Yulianah dkk, "Urgensi Perkawinan di Masa Pandemi Covid-19 Yang Dikaji Menurut Hukum Islam dan Hukum Adat Sunda" dalam Seminar Nasional Online \& Call For Paper, Fakultas Hukum, Universitas Suryakancana, 2020, 169-176. 
berada di Kelurahan Brang Biji Kecamatan Sumbawa Kabupaten Sumbawa Besar.

\section{Kebijakan Pemerintah Indonesia Selama Pandemi Covid-19}

Corona virus adalah keluarga besar virus yang menyebabkan penyakit mulai dari gejala ringan sampai berat. Ada setidaknya dua jenis coronavirus yang diketahui menyebabkan penyakit yang dapat menimbulkan gejala berat seperti Middle East Respiratory Syndrome (MERS) dan Severe Acute Respiratory Syndrome (SARS). Coronavirus Disease 2019 (Covid-19) adalah penyakit jenis baru yang belum pernah diidentifikasi sebelumnya pada manusia. Virus penyebab Covid19 ini dinamakan Sars-CoV-2. Virus corona adalah zoonosis (ditularkan antara hewan dan manusia).13

Covid-19 saat ini menjadi permasalahan dunia yang serius dengan jumlah kasusnya yang selalu mengalami peningkatan setiap harinya. Gejala-gejala umum infeksi Covid-19 seperti adanya indikasi gangguan pernapasan akut yang berbentuk demam, batuk dan sesak napas. Penularan melalui kontak dekat dan droplet, bukan melalui transmisi udara. Orang yang berisiko terinfeksi adalah yang berhubungan dekat dengan orang yang positif Covid-19. Langkah pencegahan adalah dengan menjaga kebersihan diri, mencuci tangan dengan sabun dan air mengalir atau handsanitizer.14

Situasi Covid-19 saat ini sudah berada dalam risiko tinggi pada tingkat nasional dan global. Saat ini masyarakat dihadapkan pada situasi yang mengharuskan hidup berdampingan dengan Covid-19. Oleh karena itu diperlukan pedoman pencegahan agar tetap sehat dan aman. Pemerintah telah menetapkan Covid-19 sebagai bencana non-alam sejak

13 Direktorat Jenderal Pencegahan dan Pengendalian Penyakit (P2P), Pedoman Pencegahan dan Pengendalian Coronavirus Disesase (Covid-19), (Jakarta: Kementerian Kesehatan RI, 2020), 5.

14 Anggun Wulandari, "Hubungan Karakteristik Individu dengan Pengetahuan tentang Pencegahan Corona Virus Disease 2019 pada Masyarakat di Kalimantan Selatan," dalam Jurnal Kesehatan Masyarakat Indonesia, Vol. 15, No. 1 (Mei 2020), 43. 
Maret 2020. Penyebaran Covid-19 tidak hanya terjadi di perkotaan seperti Jakarta dan sekitarnya, akan tetapi telah menyebar hingga ke pedesaan dan berdampak pada seluruh penduduk Indonesia.15 Sejauh ini pelayanan pada seluruh penduduk sudah dilaksanakan sesuai dengan aturan standar yang ditetapkan pemerintah. Hal ini diharapkan dapat mengendalikan penyebaran virus menjadi lebih menurun daripada sebelumnya. Pedoman pencegahan dan pengendalian Covid-19 disesuaikan dengan perkembangan pandemi dan ketentuan peraturan perundang-undangan yang berlaku.16

Dalam rangka penanggulangan Covid-19, pemerintah berupaya melakukan intervensi dengan vaksinasi. Pemerintah tidak hanya menanggulangi dengan cara mengharuskan menerapkan protokol kesehatan, namun juga berupaya mengendalikan pandemi Covid-19 dengan meningkatkan kekebalan masyarakat dengan vaksinasi sehingga dapat menurunkan jumlah kematian. Vaksin dinilai dapat mendukung dalam meningkatkan produktifitas sosial masyarakat, jika dilakukan dengan stategi yang tepat pada kelompok yang tepat.17

\section{Perkawinan Menurut Hukum Islam}

Perkawinan merupakan padanan dari kata nikah yang berasal dari bahasa Arab yakni al-nikāh. Secara bahasa, nikah berarti mengumpulkan. Sedangkan secara syara', perkawinan berarti akad yang telah dikenal dan sudah memenuhi rukunrukun beserta syarat-syarat tertentu untuk berkumpul,18 atau

15 Keputusan Direktorat Jenderal Pencegahan dan Pengendalian Penyakit (P2P), Petunjuk Teknis Pelaksanaan Vaksinasi Dalam Rangka Penanggulangan Pandemi Corona Virus Disease (Covid-19), (Jakarta: Kemeterian Kesehatan RI, 2021).

16 Direktorat Jenderal Pencegahan dan Pengendalian Penyakit (P2P), Pedoman Pencegahan., 7.

17 Keputusan Direktorat Jenderal Pencegahan dan Pengendalian Penyakit (P2P), Petunjuk Teknis Pelaksanaan Vaksinasi Dalam Rangka Penanggulangan Pandemi Corona Virus Disease (Covid-19), (Jakarta: Kemeterian Kesehatan RI, 2021).

18 Taqiyuddin Abū Bakar Muhammad al-Ḥusaini, Kifāyat al-Akhyār (Beirut: Dār al-Kutub al-'Ilmiyah, 2001), 460. 
akad yang memiliki ketentuan hukum kebolehan berhubungan seksual dengan lafaz nikah atau dengan kata-kata yang memiliki kesamaan makna.19

Perkawinan juga dimaknai dengan ibadah yang dilakukan oleh laki-laki dan perempuan yang nantinya terikat sebagai pasangan suami istri. Perempuan yang diambil melalui akad nikah dan menjadi istri merupakan amanat yang harus dijaga dan dilindungi.20 Perkawinan yang sudah berlangsung dipertahankan guna tercapai kehidupan yang sakinah, mawaddah, dan rahmat.

Perkawinan merupakan sesuatu yang sangat penting bagi suatu kaum. Perkawinan dilakukan sebagai upaya mempertahankan keberlangsungan hidup manusia, maka diciptakanlah berpasang-pasangan di antara manusia guna membentuk ikatan suci melalui perkawinan sebagai sebuah realitas hidup.21 Tiap-tiap daerah yang tersebar di seluruh nusantara memiliki adat istiadat yang berbeda, karena memiliki dari puluhan sampai ratusan suku bangsa di nusantara. Apa saja ritual yang dilakukan saat mengiringi jalannya prosesi perkawinan adat diperbolehkan guna mempertahankan eksistensi kearifan lokal tentu dengan tidak bertentangan dengan ajaran Islam.22

Hukum asal perkawinan itu mubah (boleh), artinya tidak diwajibkan tetapi tidak dilarang. Adanya perbedaan keadaan setiap individu dalam melaksanakan perkawinan, menyebabkan hukum perkawinan dapat menjadi sunah, wajib, makruh, dan haram. Hukum perkawinan menjadi sunah, jika dilihat dari segi jasmani sudah siap melakukan perkawinan dan dari segi materi

19 Abd Rahman Ghazaly, Fiqh Munakahat (Jakarta: Kencana, 2003), 10.

20 Amir Syarifuddin, Hukum Perkawinan Islam di Indonesia Antara Fiqh Munakahat dan Undang-Undang Perkawinan, cet. ke-1, (Jakarta: Kencana, 2006), 40-41.

21 Sitti Arafah, "Pernikahan 'Bersahaja' di Masa Pandemi Covid-19 Pada Masyarakat Bugis Kota Palopo", Mimikri: Jurnal Agama dan Kebudayaan, Vol. 6, No. 2 (November, 2020), 171.

22 Muhammad Iqbal Juliansyahzen, "Dialektika Hukum Islam dan Hukum Adat Pada Perkawinan Lelarian di Lampung Timur", Al-Ahwāl, Vol. 12, No. 1 (2019), 1. 
telah mempunyai biaya hidup untuk menafkahi istri. Wajib hukumnya, dilihat dari materi sudah cukup dan dari segi jasmani sudah mendesak untuk melakukan perkawinan, dan dikhawatirkan jika tidak segera menikah akan mendatangkan mudarat. Perkawinan hukumnya menjadi makruh bagi seseorang yang secara fisik sudah wajar untuk kawin tetapi dari sisi materi belum mencukupi dan dikhawatirkan tidak mampu menafkahi istri dan anaknya. Perkawinan hukumnya menjadi haram apabila seseorang itu menyadari bahwa dirinya tidak mampu melaksanakan hidup berumah tangga dan melaksanakan kewajiban.23

Perkawinan dalam hukum Islam adalah akad yang sangat kuat (mișāqan ghalīzan) guna mentaati perintah Allah dan bagi yang melaksanakan merupakan ibadah. Perkawinan dapat diartikan dalam arti sempit, yakni akad yang menghalalkan hubungan antara seorang laki-laki dan perempuan. Sedangkan dalam arti luas yakni akad atau ikatan antara seorang laki-laki dan perempuan untuk membentuk keluarga atau rumah tangga yang bahagia, sakinah, mawaddah, dan rahmah.

Hikmah perkawinan sangat berkaitan dan tidak dapat dilepaskan dari tujuan perkawinan itu sendiri. Allah Swt menciptakan manusia dengan maksud untuk memakmurkan bumi. Melestarikan keturunan merupakan hal yang mutlak dan menjadikan eksistensi bumi di alam semesta tidak sia-sia.24 Kehidupan manusia mustahil akan rapi, tenang dan mengasyikkan, kecuali dikelola dengan sebaik-baiknya. Hal ini dapat diwujudkan oleh perempuan yang secara naluriah mampu mengelola rumah tangga dengan baik dan wajar. Perkawinan disyariatkan agar terciptanya kehidupan manusia yang rapi dan teratur. Oleh karena itu, kehadiran istri di sisi suami, melalui perkawinan sangatlah penting. 25

Dasar yang terpenting dalam perkawinan ialah persetujuan dan kerelaan antara sang suami maupun istrinya.

23 Ahmad Atabik, "Pernikahan dan Hikmahnya Perspektif Hukum Islam," dalam Jurnal Yudisia, Vol. 5, No. 2 (Desember 2014), 293-294.

24 Ali Ahmad al-Jurjawi, Hikmah al-Tashrī’ wa Falsafatuhu (Beirut: Dār al-Fikr, t.t.), II: 6-7.

25 Ibid. 
Kerelaan adalah hal yang tidak dapat dilihat ataupun diukur. Oleh karena itu, bentuk persetujuan dan kerelaan itu di tuangkan dalam ijab qabul. Ijab adalah penyerahan dari pihak pertama, sedangkan qabul adalah penerimaan dari pihak kedua.26 Tanpa ijab qabul tidaklah sah perkawinan antara keduanya.

\section{Perkawinan Menurut Hukum Positif}

Sebagaimana diketahui bahwa ketentuan mengenai perkawinan telah diatur dalam Undang-Undang Nomor 1 Tahun 1974 dan berlaku bagi seluruh warga Indonesia tanpa terkecuali. Setelah diaturnya ketentuan ini, maka berlaku sistem Lex Specialis Derogat Lex Generalis, undang-undang yang khusus menyampingkan undang-undang yang umum. Dalam UndangUndang Nomor 1 Tahun 1974 Pasal 1 dinyatakan bahwa perkawinan ialah ikatan seorang laki-laki dan perempuan sebagai suami istri dengan tujuan membentuk keluarga yang kekal berdasarkan Ketuhanan Yang Maha Esa.27

Kompilasi Hukum Islam pada Pasal 2 menyatakan bahwa perkawinan menurut hukum Islam merupakan sebuah akad yang sangat kuat guna mentaati perintah Allah Swt dan melaksanakan merupakan ibadah. Berbeda dengan pengertian sebelumnya, menurut Burgelijk Wetboek (BW), perkawinan merupakan suatu ikatan yang memiliki hubungan keperdataan saja sebagaimana termaktub dalam Pasal 26 BW. Hal tersebut menunjukkan bahwa BW hanya memandang perkawinan sebatas ikatan keperdataan yang tidak berbeda jauh dengan perjanjian pada umumnya, sedangkan Hukum Islam memandang perkawinan merupakan sebuah ikatan yang kuat (mișāqan ghalīzan) dan berdimensi ibadah.28

Menurut R. Soetojo Prawirohamidjo, perkawinan mengandung berbagai unsur yang harus diketahui:29

26 Amir Syarifuddin, Hukum Perkawinan Islam., 61.

27 Undang-Undang Nomor 1 Tahun 1974 tentang Perkawinan, Pasal 1.

28 Indah Purbasari, Hukum Islam sebagai Hukum Positif di Indonesia (Malang: Setara Press, 2017), 77.

29 R. Soetojo Prawirohamidjo, Pluralisme dalam Perundang-Undangan di Indonesia, (Surabaya: Airlangga University Press, 1986), 38-43. 
1. Ikatan Lahir Batin

Ikatan lahir batin ialah ikatan atau hubungan antara laki-laki dan perempuan sebagai suami istri yang bertujuan membentuk keluarga. Ikatan lahir batin harus tercakup keduanya, tidak bisa ikatan lahir saja atau ikatan batin saja, dan ikatan ini disebut ikatan formal.

2. Antara seorang laki-laki dan seorang perempuan

Perkawinan hanya terbentuk melalui ikatan antara seorang laki-laki dan seorang perempuan. Perkawinan yang terbentuk dari pasangan berlawanan jenis bukan sesama jenis.

3. Sebagai Suami Istri

Ikatan perkawinan dipandang sah, apabila telah memenuhi rukun dan syarat nikah. Jika telah memenuhi itu semua, maka barulah seorang laki-laki dan perempuan dianggap sah sebagai suami istri.

4. Tujuan Perkawinan

Tujuan perkawinan ialah membentuk sebuah keluarga kekal dan erat kaitannya dengan memiliki keturunan. Perkawinan dilaksanakan sekali seumur hidup dan diharapkan akan kekal selamanya. Tujuan perkawinan juga di dalamnya terdapat hak dan kewajiban orang tua yakni pemeliharaan dan pendidikan anak.

5. Berdasarkan Ketuhanan Yang Maha Esa

Berdasarkan pancasila yakni sila pertama Ketuhanan Yang Maha Esa, maka perkawinan berhubungan erat dengan unsur lahir (jasmani) dan batin (rohani). Perkawinan menurut Undang-undang ialah ikatan lahir batin antara seorang pria dan seorang wanita sebagai pasangan suami istri dengan tujuan membentu keluarga yang sakinah, mawadah dan rahmah. Perkawinan bertujuan untuk mewujudkan kehidupan yang bahagia dan kekal berdasarakan Ketuhanan Yang Maha Esa.

\section{Perkawinan Menurut Hukum Adat}

Masyarakat adat di Indonesia beranggapan bahwa perkawinan bukan berarti sebagai "perikatan perdata" melainkan merupakan "perikatan adat" dan juga sekaligus 
“perikatan kekerabatan". Perikatan perkawinan dapat terjadi bukan semata-mata mengakibatkan hubungan keperdataan, seperti hak dan kewajiban suami istri, harta bersama, kedudukan anak, hak dan kewajiban orang tua, tetapi menyangkut pula hubungan-hubungan adat istiadat, kewarisan kekeluargaan, kekerabatan dan menyangkut upacara-upacara adat dan keagamaan. Perkawinan juga menyangkut kewajiban mentaati perintah dan larangan keagamaan, baik dalam hubungannya sesama manusia (muamalah) maupun kepada Tuhannya (ibadah) dalam pergaulan hidup agar selamanya hingga dunia serta akhirat.30

Perkawinaan menurut Tau Samawa atau orang Sumbawa adalah sebuah ikatan antara laki-laki dan perempuan dengan tujuan untuk membentuk keluarga dan memiliki keturunan sebagai penerus keluarganya. Perkawinan juga bertujuan untuk membina rumah tangga dalam hubungannya dengan hukum adat juga berkaitan dengan agama dan kepercayaan pihak istri dan suami. Dengan adanya perkawinan ini, nantinya akan melahirkan hak dan kewajiban antara suami dan istri.31 Tujuan perkawinan adat Sumbawa merupakan salah satu cara untuk menarik garis keturunan dan dibagi kedalam beberapa golongan dari keturunan yg ada sebelumnya.

Upacara keagamaan dalam adat perkawinan lazimnya dilaksanakan oleh masyarakat yang bersangkutan bersamasama untuk mengintensifkan solidaritas dalam masyarakat. Ada di antara masyarakat yang benar-benar mengetahui dan menjalankan ritus tersebut dengan tidak main-main maupun yang hanya sekedar menjalankan kewajiban saja. Budayabudaya yang sudah ada sejak dulu, masih banyak masyarakat

\footnotetext{
30 Khoirul Abror, Hukum Perkawinan dan Perceraian (Jakarta, Imprint Bumi Aksara, 2015), 42.

31Soemali, "Perkawinan Adat Sumbawa dan Permasalahan Hak Waris Bila Ditinjau Menurut Undang-Undang Nomor 1 Tahun 1974", dalam Jurnal Fakultas Hukum, Vol. XX, No. 20 (April 2011), 103.
} 
yang belum mengetahui makna di balik simbol-simbol sehingga hanya menjalani tanpa mengetahui nilai filosofisnya.32

Dalam melangsungkan perkawinan, masyarakat Sumbawa memiliki banyak prosesi dan begitu panjang sebelum sah menurut agama dan negara. Prosesi ini melibatkan banyak anggota keluarga dari pihak suami ataupun dari pihak istri, serta masyarakat untuk ikut membantu segala kegiatan sebelum menikah hingga pelaksanaan perayaan yang dikenal dengan istilah pengantan. Sebelum dilaksankannya perkawinan, ada beberapa prosesi adat yang harus dilakukan di antaranya:33

1. Bajajak

Jika lelaki ingin meminang seorang perempuan, maka ia harus melakukan pendekatan terlebih dahulu. Pendekatan dalam hal ini ialah upaya mengenal perempuan secara mendalam dari segala sisi. Biasanya dari pihak laki-laki akan mengutus kerabat dekatnya untuk bertandang ke rumah perempuan dengan tujuan pengenalan. Bila kedua telah menjalin hubungan maka disebut remanjeng (pacaran), yang mana nantinya keluarga dari masing-masing pihak akan menjodohkan dan membicarakan hubungan anak mereka ke tahap yang lebih serius.

2. Bakatoan

Bakatoan berarti datang bertanya. Pihak laki-laki nantinya akan mengutus kerabatnya sebagai wakil untuk datang membawakan pesan kepada orang tua pihak perempuan untuk menyampaikan maksud ingin meminangnya.

3. Saputes Leng

Prosesi ini adalah tahap kesepakatan yang menentukan keseluruhan acara perkawinan. Prosesi ini biasanya diwakilkan kepada para tetua atau anggota keluarga yang dianggap mampu melakukan musyawarah yang

32 Novi Widya Utami, "Wujud Kebudayaan dalam Prosesi Barodak Ritual Adat Pernikahan Sumbawa”, dalam Jurnal Retorika, Vol. 9, No. 2 (Agustus 2016), 121.

33 Muchsin Hamim, Prosesi Perkawinan Adat Sumbawa, (Mataram: Pemda NTB, 2009), 10-29. 
menghasilkan keputusan akhir mengenai penetapan biaya dan tanggal pelaksanaan acara.

4. Nyorong

Nyorong adalah upacara menghantarkan barangbarang semacam seserahan dari pihak laki-laki kepada pihak perempuan. Prosesi ini biasnaya dihadiri oleh ratusan orang yang akan beriringan mulai dari rumah pihak laki-laki dengan membawa uang atau semua barang pelengkap perkawinan untuk nantinya diserahkan kepada keluarga pihak perempuan.

5. Barodak

Barodak bermakna melulur seluruh badan dan dimeriahkan dengan musik tradisional. Barodak disini memiliki arti mensucikan kedua calon pengantin sebelum melakukan nikah atau ijab kabul. Hal ini dilakukan agar aura positif terpancar dari dalam diri kedua calon pengantin.

6. Nikah

Pernikahan di Sumbawa dilaksanakan sesuai dengan rukun dan syarat nikah yang ketentuannya diatur agama maupun negara. Pelaksanaan nikah biasnaya dihadiri oleh Petugas Pencatat Nikah, keluarga, tetangga dan orang-orang terpandang di daerah setempat.

7. Basai'

Basai' ini dikenal juga dengan resepsi yang merupakan prosesi terakhir dari segala prosesi dalam perkawinan adat Sumbawa. Basai' ini seperti resepsi pada umumnya, pengantin laki-laki dan perempuan disandingkan bersama ditempat yang sudah ditentukan keluarga.

Masyarakat Sumbawa memiliki keyakinan, bahwa adat ada untuk dilaksanakan dengan tujuan untuk menghormati warisan leluhur dan meyakini bahwa perkawinan yang dilakukan sesuai dengan tahap-tahap prosesi adat akan memiliki makna dan nilai tersendiri yang menjadikan hidup lebih baik. Masyarakat hanya melakukannya menjadi sebuah kebiasaan yang harus dilakukan saat akan menikah. Masyarakat memahami makna yang terkandung dalam tiap prosesi adat perkawinan sebagai pelengkap dalam suatu perkawinan. 


\section{Perkawinan Adat Sumbawa di Masa Pandemi Covid-19}

Semenjak terjadinya pandemi Covid-19 di hampir seluruh dunia, mengakibatkan lumpuhnya banyak aktivitas masyarakat dunia, mulai dari aktivitas bersosialisasi, perekonomian, sampai pada permasalahan perkawinan. Perkawinan adalah ibadah yang dilakukan oleh laki-laki dan perempuan yang nantinya terikat sebagai pasangan suami istri. Perempuan yang diambil melalui akad nikah dan menjadi istri merupakan amanat yang harus dijaga dan dilindungi.34 Perkawinan yang sudah berlangsung dipertahankan guna tercapai kehidupan yang sakinah, mawaddah, dan rahmah.

Di masa pandemi Covid-19 ini, pemerintah telah mengeluarkan kebijakan tata cara pelaksanaan perkawinan guna mengurangi meluas dan meningkatnya jumlah masyarakat yang terpapar Covid-19. Kementerian Agama Republik Indonesia (Kemenag) melalui Direktorat Jenderal Bimbingan Masyarakat Islam mengeluarkan kebijakan terbaru terkait pelayanan nikah. Dalam Surat Edaran tentang Pedoman Pelaksanaan Pelayanan Nikah pada masa pandemi Covid-19 yang diterbitkan 10 Juni 2020, disebutkan bahwa masyarakat diperkenankan untuk melaksanakan akad nikah di luar KUA. Meskipun demikian, terdapat syarat-syarat yang wajib dipenuhi bagi calon pengantin bila ingin tetap melaksanakan akad nikah di luar KUA. Ketentuan menikah di masa pandemi Covid-19 di anataranya prosesi akad nikah yang dilaksanakan di KUA dapat diikuti sebanyak-banyaknya oleh 10 orang dan di luar KUA diikuti sebanyak-banyaknya 20\% dari kapasitas. 35

Ritual perkawinan ini telah menjadi tradisi atau adat istiadat mayoritas masyarakat dalam merayakan dan mengenang momen terbaik dalam hidupnya. Akan tetapi, di masa pandemi Covid-19 ritual perkawinan adat seharusnya diliputi rasa kebahagiaan bisa berubah menjadi malapetaka. Ketika wabah melanda di Indonesia, para masyarakat harus menunda menggelar pesta pernikahan demi kemaslahatan

34 Amir Syarifuddin, Hukum Perkawinan Islam di Indonesia ., 40-41.

35 Sitti Arafah, "Pernikahan 'Bersahaja'., 177. 
bersama. Kebijakan pemerintah memang membuat calon pengantin dan keluarga kecewa, tetapi jika dilangsungkannya perhelatan tersebut risik yang ditimbulkan sangat besar mengingat kondisi penyebaran wabah semakin meluas. 36

Sejauh ini, pemerintah telah memberi solusi yang terbaik agar masyarakat dapat melaksanakan perkawinan dengan tetap mengikuti kebijakan yang berlaku. Namun, jika dilihat dari ritual adat perkawinan masyarakat Sumbawa, ada beberapa ritual yang coba disederhanakan untuk menyesuaikan dengan situasi Covid-19 saat ini, di antaranya ialah nyorong dan barodak. Biasanya ritual ini dihadiri dan diselenggarakan oleh banyak orang yang berkumpul di satu tempat, hal ini seharusnya tidak dilakukan di masa Covid-19. Akan tetapi mayoritas masyarakat banyak yang tidak memperdulikan protokol kesehatan dalam batasan jaga jarak di antara para tamu undangan, walaupun sudah memakai masker dan mencuci tangan.37

Ada kasus yang terjadi saat ritual adat perkawinan ini dilakukan, dimana salah seorang mempelai dikabarkan terjangkit dan positif Covid-19 setelah melakukan ritual adat barodak. Barodak sendiri dilakukan dengan cara melumuri wajah dan tangan pengantin laki-laki serta pengantin perempuan dengan odak (lulur) dan dilakukan oleh inaq odak (orang yang bertugas memakaikan lulur) sera kaum ibu-ibu. Hal ini dinilai bisa menjadi pemicu utama penyebaran Covid-19 dikarenakan sentuhan atau kontak secara langsung.38

Disisi lain, barodak memiliki makna membersihkan dan menyucikan para calon pengantin. Suci bermakna membersihkan diri secara lahir batin atau jiwa raga agar siap menghadapi kehidupan baru dalam rumah tangga. Selain itu, setelah prosesi barodak, masyarakat percaya bahwa akan menjadi pasangan suami istri yang sempurna secara adat.

36 Shofiatul Jannah, "Penundaan Perkawinan DiTengah Wabah Covid-19", Jurnal Ilmiah Ahwal Syakhshiyyah, Vol. 2, No. 1 (2020), 48-49.

37 Muhammad Azhar (Petugas Pencatat Nikah), Wawancara, Kecamatan Sumbawa, 25 November 2020.

38 Choirun Nisa (Masyarakat), Wawancara, Kecamatan Sumbawa, 25 November 2020. 
Masyarakat Sumbawa juga percaya bahwa setelah dilakukan ritual itu akan membuat calon pengantin memancarkan cahaya dan aura positif bak raja dan ratu saat akad nikah dan resepsi perkawinannya.39

Nyorong dinilai sebagai ritual yang harusnya sudah tidak terlalu penting untuk dilakukan. Ritual adat ini dianggap terlalu berlebih-lebihan dan menghamburkan harta. Dilihat di masa pandemi Covid-19 ini, sebagian masyarakat merasa ekonominya berkurang akan tetapi tetap harus melaksanakan ritual ini karena adanya tuntutan kewajiban melaksanakannya. Jika memilih tidak menjalankan salah satu prosesi adat, maka dinilai tidak sempurna perkawinan atau tanggung jika meninggalkan salah satu prosesi adat.

Nilai tentang ketuhanan dalam prosesi perkawinan adat hanya ada dalam diri masyarakat di mana kebudayaan bersangkutan itu hidup. Prosesi nyorong dan barodak misalnya, merupakan bentuk kebudayaan hasil karya manusia dalam hubungannya dengan keaagamaan dan kepercayaan masyarakat Sumbawa. Serangkaian ritual adat ini dilakukan bertujuan semata-mata rida dan izin dari Yang Maha Kuasa.

Ritual perkawinan adat yang tidak bisa lepas dari masyarakat Sumbawa, walaupun dalam masa pandemi Covid19, masyarakat merasa sangat berat jika tidak menjalankan tradisi yang sudah biasa dilaksanakan. Pemerintah tidak bisa melarang ritual adat yang dilaksanakan oleh masyarakat, hanya saja memberikan himbauan untuk selalu menjalankan segala prosesi dengan mengikuti segala protokol kesehatan. Akan tetapi, protokol kesehatan tidak serta merta dapat dilaksanakan sesuai dengan kebijakan yang diatur. Sebagian masyarakat tidak peduli dengan peningkatan penyebaran Covid-19 saat melakukan prosesi adat. Masyarakat berpikir bahwa orang yang terjangkit dan dinyakatan positif Covid-19 merupakan takdir dari orang tersebut.40

39 Novi Widya Utami, "Wujud Kebudayaan dalam Prosesi Barodak Ritual Adat Pernikahan Sumbawa”, dalam Jurnal Retorika, Vol. 9, No. 2 (Agustus 2016), 126.

40 Adnan Rifqy (Masyarakat), Wawancara, Kecamatan Sumbawa, 25 November 2020. 
Menurut masyarakat, jika ritual tidak dilaksanakan, maka akan mendapatkan bahaya. Sebagian masyarakat merasakan dilema, jika tidak melaksanakan ritual prosesi perkawinan adat akan terasa ada yang kurang dan mengganjang dalam dirinya. Akan tetapi jika melaksanakan, ditakutkan akan mendatangkan mudarat kepada calon mempelai, keluarga serta tamu undangan yang hadir. Hal ini disebabkan kurangnya koordinasi dari pemerintah dan kerjasama dengan masyarakat dalam pelaksanaan perkawinan, serta himbauan yang dirasa kurang solutif dalam mengatasi dan menjalankan kebijakan ini.41

Pemerintah tidak mengeluarkan larangan dilakukannya prosesi perkawinan atau ritual adat perkawinan selama masa pandemi Covid-19. Kebijakan yang dikeluarkan pemerintah hanya sebatas himbauan harus selalu menerapkan protokol kesehatan. Pemerintah menyerahkan pada masyarakat mengenai pemberlakuan kebijakan sesuai dengan pemahaman masyarakat. Jika terjadi kasus seperti di atas, dimana calon mempelai terpapar Covid-19, maka pemerintah menjalankan tugasnya dengan menyediakan fasilitas isolasi bagi pasien positif Covid-19 dan isolasi mandiri bagi keluarga atau hadirin yang berkontak langsung dengan mempelai yang terjangkit Covid-19.

Akibatnya, perkawinan mempelai tersebut ditunda oleh keluarga dan akan dilanjutkan kembali saat mempelai telah dinyatakan sembuh atau selesai masa isolasinya. Mayoritas masyarakat tidak mempermasalahkan dan memperdulikan lagi mengenai mempelai yang terpapar Covid-19, serta menganggap hal itu tidak pernah terjadi. Pelaksanaan prosesi adat tetap berjalan seperti sebelumnya dan dilanjutkan hingga basai' (resepsi) yang digelar secara meriah.

Masyarakat diminta untuk ikut membantu pemerintah meminimalisir penyebaran virus agar tidak semakin meluas. Masyarakat seharusnya menyediakan khusus bagi tamu dalam kondisi yang tidak sehat dan menyarankan jika tidak dalam kondisi sehat, maka tidak perlu menghadiri acara. Jika

41 Halkan (Masyarakat), Wawancara, Kecamatan Sumbawa, 25 November 2020. 
masyarakat sadar, seharusnya mengantisipasi orang-orang yang merasa tidak sehat untuk tidak perlu menghadiri prosesi perkawinan. Pemerintah menyarankan jika tetap menginginkan acara perkawinan seperti basai' (resepsi) yang mengundang banyak tamu, solusinya dengan menundanya sampai batas waktu yang kondusif.

Johns Hopkins Center for Health Security menjelaskan bahwa tidak ada tolak ukur secara pasti apakah acara dapat dilakasanakan ataupun dibatalkan. Salah satu solusi terbaik ialah membatalkan atau menunda dilaksanakannya upacara perkawinan. Pertimbangan ini dilakukan guna meminimalisir penukaran virus agar tidak menimbulkan peningkatan yang signifikan.42

Pemerintah seharusnya lebih memperhatikan dan memberi sosialisasi kepada masyarakat mengenai pentingnya melaksanakan perkawinan khususnya yang berhubungan dengan ritual adat dan resepsi. Aturan yang dikeluarkan harusnya dapat membatasi dan menyadarkan masyarakat agar menaati aturan tersebut. Kurangnya perhatian dari pemerintah terkait pelaksanaan urusan yang dilakukan oleh masyarakat, menjadikan masyarakat tidak menjalankan kebijakan atau aturan dari pemerintah dengan seluruhnya dan sepenuh hati.

Menurut pihak Kantor Urusan Agama (KUA),43 walaupun pemerintah dalam hal ini memberikan sosialisasi mengenai aturan pelaksanaan perkawinan di masa pandemi Covid-19 seperti penerapan protokol kesehatan yang sebagaimana mestinya, tetap saja dibutuhkannya partisipasi masyarakat dalam meminimalisir pelaksanaan itu terjadi. Masyarakat disini berperan sebagai pelaku pelaksanaan ritual dan seharusnya juga bertanggung jawab atas apa yang dilakukan. Sebagian masyarakat terkadang menyalahkan pemerintah tentang apa yang terjadi pada mereka, kurangnya perhatian pemerintah terhadap pandemi ini.

42 https://www.solopos.com/bila-tetap-lanjut-ini-tata-cara-menikah-saatpandemi-corona-1059629, diakses 26 November 2020 pukul 09:45 WITA. 43 Muhammad Azhar (Petugas Pencatat Nikah), Wawancara, Kecamatan Sumbawa, 25 November 2020. 
Jika dilihat dari pengalaman selama menikahkan di masa pandemi, menurut Pegawai Pencatat Nikah (PPN) KUA Sumbawa, masyarakat mengikuti aturan atau kebijakan dari pemerintah saat melakukan akad nikah di KUA atau di luar KUA. Akan tetapi, setelah akad nikah dilangsungka,n masyarakat tetap saja melaksanakan resepsi secara besar-besaran dan dihadiri oleh banyak orang.44 Di sini dapat dilihat, bahwa masyarakat masih kurang memahami tujuan dan maksud dari kebijakan yang dikeluarkan oleh pemerintah tentang penerapan protokol kesehatan.

Ritual perkawinan adat dilangsungkan masyarakat seperti saat sebelum ada pandemi Covid-19, yaitu tetap melakukan segala ritual adat dan mengundang banyak tamu untuk hadir meramaikan ritual yang dilaksanakan, walaupun mereka mengatakan tetap mengikuti protokol kesehatan dengan tetap menggunakan masker, mencuci tangan dan menjaga jarak. Menurut masyarakat, jika tidak dilangsungkan acara dengan meriah ditakutkan akan menjadi bahan omongan orang-orang, tidak enak hati jika mengundang hanya sebagian warga kampung saja dan dikarenakan ingin membuat momen perkawinan yang diharapkan sekali seumur hidup ini menjadi berkesan. Pandemi Covid-19 dianggap sudah takdir yang menimpa negara ini dan tidak akan mengganggu atau mengubah tradisi di masyarakat. Masyarakat lebih memilih mementingkan acara dilaksanakan dengan sempurna dan memikirkan konsekuensinya belakangan. 45

Sebagian masyarakat sebenarnya mengetahui konsekuensi yang akan mereka dapatkan jika tetap melakukan prosesi adat, akan tetapi rasa malu yang mereka pikirkan membuat mereka tetap melaksanakannya. Jika menelusuri lebih dalam, sebenarnya Sumbawa tidak memiliki desa adat mewajibkan para penduduk desanya mengikuti tradisi adat. Lembaga adat di Sumbawa pun tidak mengurusi mengenai proses perayaan adat, hanya mengatur ketentuan perlengkapan

44 Ibid.

45 Andin Putri (Masyarakat), Wawancara, Kecamatan Sumbawa, 25 November 2020. 
adat untuk melaksanakan prosesi adat itu sendiri. Jadi bisa disimpulkan bahwa tidak adanya aturan yang mewajibkan dilaksanakannya ritual atau prosesi adat pada perkawinan masyarakat Sumbawa dan tidak ada hukuman atau denda jika tidak melaksanakannya. Sementara itu, kebiasaan dalam masyarakat yang sudah menjadi pedoman dan pola pikir bahwa semua adat harus dilakukan dengan sempurna. Untuk beberapa wilayah lain di Indonesia dengan tegas mengeluarkan surat keputusan untuk membatasi kegiatan perkawinan seperti desa adat di wilayah kedinasan batuan telah sepakat dengan keputusan untuk membatasi prosesi perkawinan adatnya. 46

Dilihat pada sisi Hukum Islam, jika seseorang itu tidak bisa menahan nafsunya dan dikhawatirkan akan melakukan dosa atau lebih banyak melakukan mudarat, lebih baik segera melangsungkan perkawinan. Untuk melaksanakan acara perkawinan harus memperhatikan peraturan yang telah dibuat dalam Surat Edaran Direktur Jendral yang meliputi ketentuan pelaksanaan pelayanan nikah pada masa pendemi Covid-19 dan peraturan yang dibuat oleh Kementerian Dalam Negeri, tepatnya yang dikeluarkan dan ditetapkan pada akhir bulan Mei yang lalu. Namun, tidak menutup kemungkinan masih terjadinya penyebaran virus Covid-19 pada prosesi perkawinan itu berlangsung.

Masyarakat seharusnya dapat mengatasi dilema yang dihadapi dengan membuat keputusan yang menguntungkan baginya. Dimana masyarakat seharusnya menyesuaikan beberapa urusannya sesuai dengan kondisi yang terjadi saat ini dengan mempertimbangkan bahwa sebenarnya tidak melaksanakan prosesi adat selama pandemi Covid-19 menjadi pilihan terbaik. Kewajiban dalam melaksanakan prosesi adat perkawinan tidak diatur dalam rukun maupun syarat nikah, namun prosesi adat ini pun tidak bertentangan dengan Hukum Islam. Perkawinan akan tetap sah jika dilaksanakan dengan rukun dan syarat sah nikah sesuai hukum Islam tanpa

46https://radarbali.jawapos.com/read/2020/03/30/186266/pandemicorona-4-desa-adat-di-sukawati-batasi-nikah-upacara-ngaben, diakses 26 November 2020 pukul 07:00 WITA. 
melaksanakan prosesi adat dalam perkawinan. Oleh karena itu, meskipun masyarakat harus mengorbankan tradisinya dengan tidak melaksanakan adat perkawinannya selama pandemi menjadi keputusan yang benar, sebab mafsadahnya akan lebih besar jika tradisi itu dilaksanakan selama pandemi.

Pemerintah daerah seharusnya membuat kebijakan dengan meniadakan sementara prosesi perkawinan adat selama masa pandemi Covid-19. Selanjutnya, pemerintah harus memberikan penjelasan kepada masyarakat bahwa prosesi perkawinan adat bukan merupakan aturan ataupun kewajiban yang diatur dalam Hukum Islam dan tidak pula menjadi rukun ataupun syarat sah nikah. Di sisi lain, kebijakan pemerintah harus memberikan pemahaman pada masyarakat bahwa selama pandemi Covid-19 prosesi perkawinan adat lebih banyak mendatangkan mafsadah daripada kemanfaatan. Prosesi adat pun menjadi kurang bermakna jika pada akhirnya mendatangkan akibat buruk pada diri sendiri atau orang lain.

\section{Penutup}

Pemberlakuan protokol kesehatan di masa pandemi Covid-19 sejauh ini tidak mempengaruhi pelaksanaan ritual adat khususnya di Sumbawa. Di masa Pandemi ini, adat perkawinan dilakukan mengikuti protokol kesehatan dengan adanya pembatasan jumlah orang yang hadir, pembagian masker dan cuci tangan, hal ini sama sekali tidak mengurangi khidmat pelaksanaan adat perkawinan. Akan tetapi, dalam menerapkan protokol kesehatan, ternyata masih ada dilema di masyarakat mengenai pelaksanaan adat dalam perkawinan walaupun prosesnya telah disederahanakan.

Dengan demikian, kita dapat menarik kesimpulan bahwa melakukan perkawinan itu memang dianjurkan oleh agama dan sebagai penyempurna agama, namun jika dilihat dari kondisi sekarang yang masih belum stabil dan masih dihantui oleh pendemi virus Covid-19, maka lebih baik menunda pelaksaannya atau meniadakan prosesi adat dengan tujuan memelihara kesehatan dan keselamatan jiwa. Apabila masyarakatmelaksanakan maka, pelaksanaan prosesi 
perkawinan itu yang hanya menghadirkan keluarga inti saja dan sesuai ketentuan yang telah ditetapkan oleh pemerintah.

\section{Daftar Pustaka}

Abror, Khoirul. Hukum Perkawinan dan Perceraian, Jakarta, Imprint Bumi Aksara, 2015.

Arafah, Sitti. "Pernikahan 'Bersahaja' di Masa Pandemi Covid-19

Pada Masyarakat Bugis Kota Palopo". Mimikri: Jurnal Agama dan Kebudayaan. Vol. 6. No. 2 (November, 2020). Atabik, Ahmad. "Pernikahan dan Hikmahnya Perspektif Hukum Islam," dalam Jurnal Yudisia, Vol. 5, No. 2 Desember 2014. Direktorat Jenderal Pencegahan dan Pengendalian Penyakit (P2P), Pedoman Pencegahan dan Pengendalian Coronavirus Disesase (Covid-19), Jakarta: Kementerian Kesehatan RI, 2020.

Ghazaly, Abd Rahman. Fiqh Munakahat, Jakarta: Kencana, 2003. Hamim, Muchsin. Prosesi Perkawinan Adat Sumbawa, Mataram: Pemda NTB, 2009.

Ḥusaini (al), Taqiyuddin Abū Bakar Muhammad Kifāyat alAkhyār, Beirut: Dār al-Kutub al-'Ilmiyah, 2001.

Jurjāwī (al), ‘Ali Ahmad. Hikmah at-Tashrī’ wa Falsafatuhu, Beirūt: Dār al-Fikr, t.t.).

Muhyiddin, "Covid-19, New Normal dan Perencanaan

Pembangunan di Indonesia", The Indonesian Journal of Development Planning, Vol. IV, No. 2 (Juni, 2020).

Patau, Qalbi Triundayani L. "'Urf Terhadap Tradisi Barodak Rapancar Sebelum Perkawinan", Sakina: Journal of Family Studies, Vol. 5, No. 12021.

Prawirohamidjo, R. Soetojo. Pluralisme dalam PerundangUndangan di Indonesia, Surabaya: Airlangga University Press, 1986.

Pujileksono, Sugeng. Pengantar Antropologi, Malang: Kelompok Intrans Pubising, 2015.

Purbasari, Indah. Hukum Islam sebagai Hukum Positif di Indonesia, Malang: Setara Press, 2017.

Soemali, "Perkawinan Adat Sumbawa dan Permasalahan Hak Waris Bila Ditinjau Menurut Undang-Undang Nomor 1 
Tahun 1974", dalam Jurnal Fakultas Hukum, Vol. XX, No. 20 (April 2011).

Syarifuddin, Amir. Hukum Perkawinan Islam di Indonesia Antara

Fiqh Munakahat dan Undang-Undang Perkawinan, cet. ke-

1, Jakarta: Kencana, 2006.

. Hukum Perkawinan Islam di Indonesia Antara

Fiqh Munakahat dan Undang-Undang Perkawinan, Jakarta: Kencana, 2007.

Utami, Novi Widya."Wujud Kebudayaan dalam Prosesi Barodak Ritual Adat Pernikahan Sumbawa", dalam Jurnal Retorika, Vol. 9, No. 2 Agustus 2016.

Wulandari, Anggun. "Hubungan Karakteristik Individu dengan Pengetahuan tentang Pencegahan Corona Virus Disease 2019 pada Masyarakat di Kalimantan Selatan," dalam Jurnal Kesehatan Masyarakat Indonesia, Vol. 15, No. 1 Mei 2020.

Marpi, Yapiter. "Keabsahan Hukum Pernikahan Tanpa Adanya Walimatul Ursy di Masa Kahar Pandemi Covid-19", AsSyar'i: Jurnal Bimbingan \& Konseling Keluarga, Vol. 2, No. 2 (2020).

Yulianah, Yuyun dkk. "Urgensi Perkawinan di Masa Pandemi Covid-19 yang Dikaji Menurut Hukum Islam dan Hukum Adat Sunda" dalam Seminar Nasional Online \& Call For Paper, Fakultas Hukum, Universitas Suryakancana, 2020. Undang-Undang No. 1 Tahun 1974 tentang Perkawinan.

Keputusan Direktorat Jenderal Pencegahan dan Pengendalian

Penyakit (P2P), Petunjuk Teknis Pelaksanaan Vaksinasi dalam Rangka Penanggulangan Pandemi Corona Virus Disease (Covid-19), (Jakarta: Kemeterian Kesehatan RI, 2021).

Nisa, Choirun (Masyarakat). Wawancara. Kecamatan Sumbawa, 25 November 2020.

Halkan (Masyarakat), Wawancara, Kecamatan Sumbawa, 25 November 2020.

Bapak Darmo (Masyarakat), Wawancara, Kelurahan Brangbiji, Kecamatan Sumbawa, 25 November 2020. 
Fatihatul Anhar Azzulfa dan Afnan Riani Cahya Ananda

Putri, Andin (Masyarakat). Wawancara. Kecamatan Sumbawa, 25 November 2020.

Rifqy, Adnan (Masyarakat). Wawancara. Kecamatan Sumbawa, 25 November 2020.

Azhar, Muhammad (Petugas Pencatat Nikah). Wawancara. Kecamatan Sumbawa, 25 November 2020. 